\title{
Prostatic FNAC, Evaluation as a Diagnostic Tool and Correlation with Serum Prostate Specific Antigen
}

\author{
Alka Upreti1 ${ }^{1}$ Sanat Kumar Mohanty² \\ ${ }^{1}$ Department of Pathology, HIMS, Ataria, Sitapur, Uttar Pradesh, India. ${ }^{2}$ Department of Surgery, South Eastern Coalfield Ltd. \\ India.
}

\section{ABSTRACT}

\section{BACKGROUND}

For proper diagnosis of prostatic diseases there are many investigations starting from per rectal examination, transurethral cystoscopy, fine needle aspiration cytology, six quadrants core biopsy, serum enzymes estimation like prostate specific antigen and acid phosphatase and ultrasound examination. Out of these, only FNAC and core biopsy prostatic tissue can be examined for final diagnosis. For examination of core biopsy, a complete histopathology set up is required with a trained technician but FNAC is a simple outpatient procedure where no trained technician is required. It requires only few reagents and a qualified pathologist. Since geriatric population is increasing day by day and prostatic adenocarcinoma is now second commonest malignancy in males, diagnosis is very important to reduce morbidity and mortality caused by this disease.

\section{METHODS}

The study group consisted of 40 patients who presented with symptoms of obstructive uropathy and on DRE (Direct Rectal Examination) had prostatic enlargement. FNAC was done with Franzen canula using non aspiration technique and serum PSA was done by ELISA method.

\section{RESULTS}

All the patients in our study were above 50 yrs. of age. Out of 40 cases 5 cases were of prostatitis they were mostly bellow 70 yrs. of age. 10 BHP and 25 prostatic adenocarcinomas. The carcinoma cases were almost all above the age of 70 yrs. BHP and carcinoma cases were correlated with histopathology whereas prostatitis cases were followed up clinically. Our sensitivity for benign lesion was $100 \%$ and for malignancy $92 \%$. The serum PSA was up to $6.8 \mathrm{ng} / \mathrm{ml}$ in benign conditions and above $10 \mathrm{ng} / \mathrm{ml}$ in adenocarcinomas.

\section{CONCLUSIONS}

FNAC prostate is very sensitive and reliable diagnostic tool. It is painless OPD procedure without complications and can be done easily in any small setup, where facility of histopathology is not available. The procedure is well accepted by geriatric population due to its simplicity and being a painless OPD procedure. Serum PSA cannot be used as screening test for prostatic carcinoma but can be used for prognostic indicator.

\section{KEY WORDS}

Prostate, Fine Needle Aspiration Cytology, BHP, Prostatic Adenocarcinoma, Prostatitis, PSA
Corresponding Author: Dr. Alka Upreti,

House No. 8/3, Sector 10,

Indira Nagar, Lucknow-226016,

Uttar Pradesh, India.

E-mail: alkaupreti@gmail.com

DOI: $10.14260 /$ jemds/2020/1

Financial or Other Competing Interests: None.

How to Cite This Article:

Upreti A, Mohanty SK. Prostatic FNAC, evaluation as a diagnostic tool and correlation with serum prostate specific antigen. J. Evolution Med. Dent. Sci. 2020;9(01):1-4, DOI: 10.14260/jemds/2020/1

Submission 12-08-2019,

Peer Review 22-12-2019,

Acceptance 28-12-2019,

Published 06-01-2020.

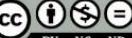




\section{BACKGROUND}

Prostate is an important organ of males and many prostatic diseases are seen in older age group. There are range of investigations ranging from per rectal examination, transurethral cystoscopy, fine needle aspiration cytology, six quadrant core biopsy, serum enzymes estimation like prostate specific antigen and acid phosphatase and per rectal ultrasound examination. For examination of core biopsy, a complete histopathology set up is required with a trained technician but FNAC is a simple outpatient procedure where no trained technician is required, it requires only few reagents and qualified pathologist. The technique of FNAC prostate was started by Franzen, Gietz and Zaicek in 1960 by transperitoneal route later it was replaced by transrectal route and popularized by Franzen instrumentation ${ }^{1}$. In male patients with disseminated malignancy of unknown origin FNA prostate is a simple method of investigation useful to search primary malignancy. Out of all only FNAC and core biopsy prostatic tissue can be examined for final diagnosis. Since geriatric population is increasing day by day Prostatic adenocarcinoma is also increasing and it has been noted that now as second commonest malignancy in males. Diagnosis is very important to reduce morbidity and mortality caused by this disease.

Prostatic carcinoma of male is also considered as counter part of breast carcinoma in females as both are hormones dependent ${ }^{2}$. As we know that young population is migrating to different places leaving old parents to live alone. Therefore, if prostatic carcinoma can be diagnosed early with a simple noninvasive method for which no help or admission to hospital is required, it will be accepted by them. The early diagnosis and treatment will reduce mortality and morbidity caused by the disease. They would also be saved from financial expenditure would have occurred on diagnostic investigations and treatment if deducted late.

The aim of this study was to assess utility of FNAC in a remote place for diagnosis of prostatic malignancy.

\section{METHODS}

This study is retrospective study from the work done in an 80 bedded hospital situated in Chirimiri a project of South Eastern Coalfields Ltd which is situated in Korea dist. of Chhattisgarh state from 1999 to 2002. This hospital is situated in very interior and any Medical College at that time was 250-300 Kms with poor communication modes.

The study group consist of 40 cases presented with obstructive uropathy symptoms in surgery outpatient dept and on DRE (Direct Rectal Examination) had enlarged prostate. Sample size was taken based on the convenience of the study. Procedure was done as outpatient procedure. Patient was asked to lie down in left lateral position with Right knee folded up to umbilicus. He was asked to take deep breath and at the same time Franzen canula was inserted per rectally guided by index finger. Site was selected for FNAC and needle introduced through guide. No local anaesthesia was given, and no aspiration was done. Slides were prepared from all the material received, air dried and stained with May Grunwald Giemsa stain. Simultaneously blood was also drawn for total PSA estimation. For histopathology the tissue was sent to Bilaspur District after operation at our hospital because the facility was not in our remotely placed hospital. Therefore, the histopathological reports were totally unbiased as done by different pathologist. The study was approved by the Ethics Committee and informed consent was obtained.

\section{Statistical Analysis}

The Statistical Package for Social Science \{SPSS \} Version 20 will be used for Data Analysis. Mean, median, and SD are used to describe quantitative data. Qualitative data are summarized using frequency and percentage.

\section{RESULTS}

In present study 40 patients of prostatic lesions were studied by transrectal FNAC there were only 4 cases in the age of 50 to 60 yrs., and all showed benign lesions. 6 cases in 60 to 70 yrs., in this group only one case adenocarcinoma was diagnosed, rest 30 cases were above 70 yrs., and 24 cased were diagnosed adenocarcinoma. Histopathological correlation was possible only in 24 cases as 11 cases were either of prostatitis (5 cases) or of late stage with distant metastasis (4 cases).

\section{Acute and Chronic Prostatitis}

5 cases were of prostatitis (acute and chronic). Cytological picture in acute prostatitis the aspirate was pus like cytological smear showed marked infiltration of acute inflammatory cells i.e., polymorphs and many macrophages, necrotic tissue in background with groups of normal appearing epithelial cells at places mild nuclear atypia was seen. In chronic prostatitis aspirate was milky white cytological smear showed infiltration of chronic inflammatory cells i.e., lymphocytes and plasma cells with groups of normal appearing epithelial cells. Biopsy not performed culture and sensitivity of prostatic fluid was done and patient treated accordingly followed up and found cured.

\section{Benign Hyperplasia Prostate}

10 cases were of BHP (25\%). All cases presented with obstructive uropathy and on per rectal digital examination showed enlarge nodular or smooth prostate. On aspiration milky white/watery aspirate was yielded. Cytological smear was highly cellular and showed many cohesive clusters of monolayered sheets of normal looking epithelial cells with distinct cell border, vesicular centrally placed nuclei with smooth nuclear membrane, abundant pale cytoplasm giving honeycomb pattern of cells. Most of the cells shows coarse cytoplasmic granularity.

\section{Histopathology}

Histopathology showed prostatic glands of variable sizes with epithelial stratification and intraluminal corpora amylacea and highly cellular stroma.

\section{Prostatic Adenocarcinoma}

In our study most of the cases were of adenocarcinoma 25 out of 40 cases i.e., $62.5 \%$ almost all the cases were above 70 yrs., of age except one case bellow 70 yrs., of age. Most of the patients presented with obstructive uropathy and nonspecific 
symptoms like backache. On per rectal examination prostate was enlarged with nodules hard in consistency. FNAC was done from different nodules and yielded haemorrhagic fluid.

Cytological smear shows cell rich smear with many free cells indicating decreased cellular cohesion. Nuclear crowding indicated by multi layering of nuclei, nuclear overlapping, nuclear pleomorphism, absence of cytoplasmic granules and altered nuclear cytoplasmic ratio seen. Nuclear membrane shows irregularity. The grading of adenocarcinoma was done as per guideline given in Fine needle aspiration cytology by S. R Orell third edition. On cytological examination of 40 cases two (2\%) were diagnosed as acute prostatitis, three (7.5\%) were diagnosed chronic prostatitis, ten (25\%) were diagnosed BHP and 25 (62.5) were diagnosed as adenocarcinoma.

The adenocarcinoma was further differentiated in grade I i.e. well differentiated, grade II moderately differentiated and Grade III poorly differentiated. All cases were followed up and histopathological correlation was seen in all BPH and adenocarcinoma cases. It has been observed that cytological diagnosis was $100 \%$ correct in acute and chronic prostatitis, all case of BPH and adenocarcinoma Grade II and above. In grade I adenocarcinoma false positive cases were 33.33\%. The number of false positive was quite high, reason for this was that even with little doubt the case was over reported so that in no case malignancy is missed. No false negative case was found. (Table 1) It was observed that maximum no of patients in our study were above 70 yrs. of age (75\%). (Table 2). It was observed that in all benign conditions, serum PSA was between 1.6 to $6.8 \mathrm{ng} / \mathrm{ml}$ except in one case of chronic prostatitis where initial PAS was $14 \mathrm{ng} / \mathrm{ml}$, but on follow up PSA fallen to $4.3 \mathrm{ng} / \mathrm{ml}$ after one month. (Table 3 )

In grade I adenocarcinoma PSA levels were in range of 6$13 \mathrm{ng} / \mathrm{ml}$. Two cases of Grade I adenocarcinoma on histopathological examination turned out to be cases of BPH, but in both cases PSA level was $>10 \mathrm{ng} / \mathrm{ml}$, whereas into case though the PSA level was $<10 \mathrm{ng} / \mathrm{ml}$, the cytological diagnosis of Grade I adenocarcinoma was confirmed on histopathological examination. In all cases of Grade II and above adenocarcinoma the PSA levels were $>15 \mathrm{ng} / \mathrm{ml}$. Therefore, Grade I adenocarcinoma and serum PSA levels up to $14 \mathrm{ng} / \mathrm{ml}$ lies in gray zone. (Table 4 )

\begin{tabular}{|c|c|c|c|c|}
\hline $\begin{array}{c}\text { Sl. } \\
\text { No. }\end{array}$ & $\begin{array}{c}\text { Cytological } \\
\text { Diagnosis }\end{array}$ & $\begin{array}{c}\text { No. of } \\
\text { Cases }\end{array}$ & $\mathbf{\%}$ & $\begin{array}{c}\text { Histopathological } \\
\text { Correlation }\end{array}$ \\
\hline 1 & Acuteprostatitis & 2 & 5 & Not available \\
\hline 2 & Chronic prostatitis & 3 & 7.5 & Not available prostatic massage fluid culture +ve \\
\hline 3 & BPH & 10 & 25 & 10 consistent with cytological diagnosis \\
\hline 4 & Adenocarcinoma & 25 & 62.5 & \\
\hline a & Grade I & 6 & & 6 four consistent with cytological diagnosis \\
\hline b & Grade II & 10 & & 10 All consistent with cytological diagnosis \\
\hline c & Grade III & 9 & & $\begin{array}{c}5 \text { consistent with cytological diagnosis, } \\
\text { rest 4 had distant metastasis }\end{array}$ \\
\hline & \multicolumn{7}{|c|}{ Total } & $\mathbf{4 0}$ & $\mathbf{1 0 0} \%$ & \\
\hline & Table 1. Cytological Diagnosis and Histopathological Correlation \\
\hline
\end{tabular}

\begin{tabular}{|c|c|c|c|c|c|c|}
\hline $\begin{array}{c}\text { Age } \\
\text { Group }\end{array}$ & $\begin{array}{c}\text { Acute } \\
\text { Prostatitis }\end{array}$ & $\begin{array}{c}\text { Chronic } \\
\text { Prostatitis }\end{array}$ & BPH & $\begin{array}{c}\text { Adeno- } \\
\text { carcinoma }\end{array}$ & Total & $\%$ \\
\hline $50-60$ & 1 & 1 & 2 & nil & 4 & $10 \%$ \\
\hline $61-70$ & 1 & 1 & 3 & 1 & 6 & $15 \%$ \\
\hline $71-80$ & nil & 1 & 3 & 13 & 17 & $42.5 \%$ \\
\hline$\geq 81$ & nil & nil & 2 & 11 & 13 & $32.5 \%$ \\
\hline Total & $\mathbf{2}$ & $\mathbf{3}$ & $\mathbf{1 0}$ & $\mathbf{2 5}$ & $\mathbf{4 0}$ & $\mathbf{1 0 0 \%}$ \\
\hline \multicolumn{7}{|c|}{ Table 2. Age Wise Distribution of Cases } \\
\hline
\end{tabular}

\begin{tabular}{|c|c|c|c|}
\hline Sl. No. & Cytological Diagnosis & No. of Cases & PSA Levels \\
\hline 1 & Acute prostatitis & 2 & $<2 \mathrm{ng} / \mathrm{ml}$ \\
\hline 2 & Chronic prostatitis & 3 & $<4 \mathrm{ng} / \mathrm{ml}$ \\
\hline 3 & BPH & 10 & $3.6-6.8 \mathrm{ng} / \mathrm{ml}<7 \mathrm{ng} / \mathrm{ml}$ \\
\hline Total & & 15 & \\
\hline \multicolumn{3}{|c|}{ Table 3. Correlation of Cytological Diagnosis with PSA }
\end{tabular}
in Benign Conditions

\begin{tabular}{|c|c|c|}
\hline Grade of Adenocarcinoma & No. of Cases & PSA Levels \\
\hline Grade 1 & 6 & $6-13 \mathrm{ng} / \mathrm{ml}$ \\
\hline Grade II & 10 & $>15 \mathrm{ng} / \mathrm{ml}$ \\
\hline Grade III & 9 & $>15 \mathrm{ng} / \mathrm{ml}$ \\
\hline Table 4. Correlation of PSA Levels in Different Grades of Adenocarcinoma
\end{tabular}

\begin{tabular}{|c|c|c|c|}
\hline Name of Author & No. of Cases & False Positive & False Negative \\
\hline Chayanika et al & 121 & 1.65 & 4.76 \\
\hline Reddy et al & 27 & $0 \%$ & $15.79 \%$ \\
\hline Present study & 40 & $5 \%$ & $0 \%$ \\
\hline \multicolumn{2}{|r|}{ Table 5. Incidence of False Positive and False Negative } \\
Reports in Different Studies \\
\hline
\end{tabular}

\section{DISCUSSION}

Prostatic FNAC is still not as commonly used as FNAC of other organs. FNAC should be used as first line of diagnostic investigation in all cases where prostate is found abnormal in consistency or enlarged. It is simple, painless outpatient procedure without complications and is also coat effective. In our study, adenocarcinoma constituted $62.5 \%$. Dr. Janardan V Bhatt et al in his study found BPH as common lesion $93.94 \%$. D Javan B et al $^{1}$ and Arun Chitale also found BPH as common lesion 835 and $89 \%$ respectively the age group included in Janardan et al study was 38 to 80 yrs. and they observed that BPH was more common in 38 to 63 yrs. while adenocarcinoma was more in 58 to $80 \mathrm{yrs}$. In our study the false positive cases were $8 \%$ all of grade I adenocarcinoma and no false negative carcinoma. Reddy et $\mathrm{al}^{2}$ reported $15.79 \%$ false negative. Chayanika et al $^{3}$ reported 4.79 false negative and $1.65 \%$ false positive cases, their study group was of 121 cases. Reddy et $\mathrm{al}^{2}$ reported $84.21 \%$ accuracy of FNAC in detecting malignancy. In our study diagnostic accuracy was $92 \%$ in malignancy and $100 \%$ in benign conditions. Sung J. C. et al ${ }^{4}$ studied prostatic biopsy among the men aged more than 70 yrs. and found malignancy in 59.8\% cases and when the age group range selected was above 80 yrs. then $81 \%$ had malignancy. Sharma et $\mathrm{al}^{5}$ also reported malignancy in $69.8 \%$ cases in their study of 36 cases. In our study malignancy was in $62.5 \%$ cases. Esposti et al $60 \%$ case of carcinoma in study of 350 cases.

In our study false high $(>10 \mathrm{ng} / \mathrm{ml})$ PSA was found in three cases and false low $(<10 \mathrm{ng} / \mathrm{ml})$ in two cases. American cancer society has also specified that PSA is insensitive (False negative in $35 \%$ and nonspecific raised in $65 \%$ ) for detection of cancer prostate. Poiton MD et al had considered elevated PSA when it was $>12 \mathrm{ng} / \mathrm{ml}$, whereas Sharma et $\mathrm{al}^{5}$ has observed $>10 \mathrm{ng} / \mathrm{ml}$ in all malignant cases. We noted that $>15$ $\mathrm{ng} / \mathrm{ml}$ indicated definite malignancy. Gray zone was with levels between 6 to $14 \mathrm{ng} / \mathrm{ml}$.

\section{CONCLUSIONS}

FNAC can be used for diagnosis of prostatic lesions with enlarged prostate on DRE. In case of Grade I adenocarcinoma, 
cytological findings should be correlated with PSA levels before giving diagnosis of carcinoma. Therefore, it is of great help for patients of small towns where there is no facility of ultrasound \& histopathology setup.

\section{REFERENCES}

[1] Djavan B, Zlotta A, Remzi M, et al. Optimal predictor of prostatic cancer on repeat prostate biopsy: a prospective study of 1,051 men. Journal of Urology 2000;163(4):1144-9.

[2] Reddy DS, SandhyaRani M. Efficacy of FNAC in early diagnosis of prostatic carcinoma. IAPM 2016;3(10):1004.
[3] Pantola C, Kala S, Singh PK, et al. A correlative study between transrectal FNAC and histology of the prostate for detection of prostate carcinoma. IOSR Journal of Dental and Medical Science 2012;1(I):18-20.

[4] Sung JC, Kabalin JN, Terris MK. Prostate cancer detection, characterization and clinical outcome in men aged 70yrs and older referred for transrectal ultrasound and prostate biopsies. Urology 2000;56(2):295-301.

[5] Verma AK, Sharma AK, Bisht D, et al. Role of AGNOR in clinically suspicious prostatic nodule on cytology. Indian Journal of Cytology 2006;23(2):75-8.

[6] Esposti PL. Aspiration biopsy cytology in the diagnosis and management of prostatic carcinoma. Stockholm, Stahl and Accidenstryct 1974. 